\title{
Effect of Vitamin E and Selenium Supplementation on Serum Metabolites Concentration during Peri-Parturient Stress Period in Crossbred Cows
}

\author{
A. Patel Pankaj ${ }^{1 *}$, A. Khatti ${ }^{2}$, A. Paul ${ }^{1}$, D. Mahato ${ }^{1}$, V. P. Maurya ${ }^{1}$ and G. Singh ${ }^{1}$ \\ ${ }^{1}$ Division of Physiology and climatology, ${ }^{2}$ Animal Reproduction Division, \\ ICAR-Indian Veterinary Research Institute, Izzatnagar, Bareilly, U.P., India-243122 \\ *Corresponding author
}

\section{A B S T R A C T}

Ke y w o r d s
Peri-parturient
period, Vitamin E,
Selenium, serum
metabolites,
Negative energy
balance

\section{Keywords}

Peri-parturient period, Vitamin E Selenium, serum

Negative energy

Article Info

Accepted:

Available Online:

10 June 2020
Metabolic and physiological changes occurring during the peri-parturient period causes extensive metabolic stress in cows, concurrent with immunosuppression during this period. In the current study, we investigated, the possible relationship between vitamin E, selenium, high energy diet supplementation and its effects on serum metabolites. The present study was conducted on a total of 30 animals, 15 were in each group (Control and Treatment). The treatment group was supplemented with $80 \mathrm{IU}$ Vitamin E $/ \mathrm{kg}$ Dry matter intake (DMI) and $0.3 \mathrm{mg}$ Selenium $/ \mathrm{kg}$ DMI, from 4 weeks before calving to 8 weeks after calving, including the day of parturition. We observed significantly $(p<0.05)$ higher cholesterol concentrations in the treatment group rather than the control group. The level of urea remained high in the control group than treatment; however, no changes in the Total protein, albumin and ALT. The alterations in the serum metabolite's concentrations are due to the positive effects of vitamin e and selenium, which have antioxidant roles.

\section{Introduction}

The transition period in pregnant cows is between late parturition and early lactation, commonly defined as a period between 3 weeks before calving to 3 weeks after calving (Drackley, 1999). During the periparturient period, animals express voluntary decrease in feed intake that is linked with physical, behavioural, hormonal and metabolic changes around transition period (Allen et al., 2005).
Prioritisation of nutrients towards mammary gland further aggravates the demand for nutrients, and as a result, cow enters in negative energy balance (NEB) (Bell, 1995).

With the onset of milk production, the extra metabolic activity of the mammary gland increases the overall energy requisites by roughly fourfold and or about 85 per cent of the total body glucose is utilised for the mammary gland to maintain a large amount of 
milk production (Bickerstaffe et al., 1974). Within three weeks of the start of lactation, milk yields and constituents rise significantly and surpass feed consumption (Bertoni et al., 2009).

Dairy cows respond to NEB by mobilising adipose energy depots and converting skeletal muscles into significant sites for the use of fat-derived fuels, such as non-esterified fatty acids (NEFA) and ketone, enabling glucose to be transferred to fetal metabolism and lactose synthesis (Herdt, 2000).

An impaired balance between lipogenesis and lipolysis in adipose tissue during periods of decreased food and energy supply leads to lipid mobilisation as an adaptive response of mammals for survival. NEFA mainly accumulates as triglycerides (TGs) in liver cells as a consequence of reduced lipoprotein synthesis (VLDL) in hepatocytes (González et al., 2011).

Increased metabolic demands at the time of parturition encourage the production of reactive oxygen species (Sordillo, 2005). Cholesterol is the crucial molecule for the genesis of steroid hormones (Guedon et al., 1999). Various authors have cited that it's concentration decreases with increased oxidative stress during parturition (González et al., 2011; Djoković et al., 2013)

The enzymes aspartate aminotransferase (AST) and alanine aminotransferase (ALT) form the basis for amino acid and carbohydrate metabolism. Elevated transaminase concentrations in blood plasma can result from increased hepatocyte membrane permeability or its degradation.

Vitamin $\mathrm{E}$ is an effective antioxidant that has been proven to play a significant role in the immune response and wellbeing of dairy cows (Weiss and Spears, 2006). Further,
Selenium functions as an essential component of a family of glutathione peroxidase enzymes within the antioxidant system. Thus, the objective of the experiment was to study the effects of Vitamin E, Selenium and high energy diet supplementation during the periparturient period, on serum metabolites concentration.

\section{Materials and Methods}

The study was conducted at the LPM farm ICAR-IVRI, with the approval of the institutional animal ethics committee. A total of 30 crossbred vrindavani cattle having parity between $2^{\text {nd }}$ to $4^{\text {th }}$ were used, with milk production at least above 10 litres/day.

Animals were maintained under standard managemental conditions. Further, animals of treatment group supplemented Vitamin E (DL-a-tocopherol acetate CDH, India) @ 80 $\mathrm{IU} / \mathrm{kg}$ dry matter intake (DMI) and Selenium (In the inorganic form Sodium selenite, CDH, India) @ $0.3 \mathrm{mg} / \mathrm{kg}$ DMI from 4 weeks before calving to 8 weeks after calving, in addition to the supplementation, 20 percent extra concentrate was also provided to the treatment group cows. However, no supplementation and extra concentrate were offered to the control group cows.

Blood serum was collected using BD Vacutainer $®$ tubes, from 4 weeks before calving to 8 weeks after calving, at the weekly interval, including the day of parturition. The samples were stored in -20 refrigerator until further use. The kits used in the study for the measurement of cholesterol, total protein, albumin, urea and ALT were procured from the Coral clinical systems (Tulip Diagnostics Pvt. Ltd.). The experimental data were analysed using SPSS 22.0 software. The test used to determine statistical significance $(\mathrm{P}<0.05)$ was repeated measures two way ANOVA. 


\section{Results and Discussion}

The Mean and SE of serum metabolite's during the transition period are presented in table 1. Excessive lipomolization during the periparturient period from the body reserves to meet the increased energy demands lead to a rise in lipogenesis and ketogenesis, reduced glucose formation in hepatocytes and alterations in the morphology of hepatocytes, causes decreasing triglycerides, total protein, albumin, urea, and glucose concentrations in serum (Djoković et al., 2011; Gonzalez et al., 2011).

In the current study, we observed a declining trend in the level of serum protein and albumin, from 4 weeks before parturition to $1^{\text {st }}$ week after calving, and after that, it has steadily increased. A minimum value of albumin and protein and was observed on the day of parturition in both the groups, however, no significant difference was observed between the groups, which are in agreement with findings of Chandra et al., (2018), who supplemented vitamin E and Zinc to the periparturient cows. The concentrations of blood cholesterol constitute both hepatic and intestinal secretion, while the latter may also be changed by feed consumption and dietary profile (Duske et al., 2009). In the current experiment, cholesterol level was also found to decline as parturition approaches and then after gradually rises to maintain plateau in the research.

Significant higher $(p<0.05)$ level of cholesterol was observed at $1^{\text {st }}$ week and $4^{\text {th }}$ to $8^{\text {th }}$ week after parturition in the treatment group. Increased demand for production of steroid hormones to maintain pregnancy (progesterone) and to prepare mammary glands for upcoming lactation (estrogen, progesterone) may be considered to be the primary cause of decreasing total serum cholesterol concentrations in dairy animals during the last pregnancy phase (Pysera and Opalka, 2000). Our values for cholesterol are within the range, as reported by Trevisi et al., (2012).

Increased concentration in the treatment group is in agreement with Bhimte et al., (2018), who supplemented Vit. E, Se, Cu and $\mathrm{Zn}$. However, it is in contradiction with the findings of Bass and Thompson (1999). The decrease in serum cholesterol level in the control group is further associated with the increased oxidative stress (Esposito et al., 2014).

The serum enzyme ALT level was found to be gradually increased up to week $6^{\text {th }}$. Though there was an increasing trend after parturition in both the groups, we observed no significant $(p<0.05)$ change at any time point between the groups. Authors say that the serum ALT level remains high in the ketotic cows (Du et al., 2017). Our study postulates that there were no effects of supplementation on ALT values.

The concentration of serum urea level also showed a declining trend from $4^{\text {th }}$ week before parturition to calving, after that it showed a sharp rise in its concentration up to $4^{\text {th }}$ week in both the experiments. However, significantly lower values $(p<0.05)$ in the treatment group was observed at $3^{\text {rd }}$ to $5^{\text {th }}$ week. In late pregnancy demand for foetal development is limited by either protein or energy supply and the availability of glucose for oxidation is supplemented by increased use of amino acids at the cost of protein biosynthesis, thus stimulating the synthesis of urea (Bell, 1995). The lesser concentration of serum urea in the supplemented groups our study may be due to the positive effects of Vitamin E, Selenium, and high energy diet, which mitigate the stress and decreases glomerular filtration rate(Chandra et al., 2018). 
Table.1 Mean \pm SE of Blood-biochemical profiles of transition Vrindavani crossbred cattle

\begin{tabular}{|c|c|c|c|c|c|c|}
\hline \multicolumn{2}{|c|}{ Weeks } & \multirow{2}{*}{$\begin{array}{l}\text { Total Protein } \\
\text { (gm/dl) }\end{array}$} & \multirow{2}{*}{$\begin{array}{l}\begin{array}{l}\text { Albumin } \\
\text { (g/dl) }\end{array} \\
3.71 \pm 0.25\end{array}$} & \multirow{2}{*}{$\begin{array}{l}\begin{array}{l}\text { Cholesterol } \\
\text { (mg/dl) }\end{array} \\
114.40 \pm 2.79\end{array}$} & \multirow{2}{*}{$\begin{array}{l}\text { SGPT U/ml } \\
18.37 \pm 1.16\end{array}$} & \multirow{2}{*}{$\begin{array}{l}\begin{array}{l}\text { Urea } \\
(\mathbf{m g} / \mathbf{d l})\end{array} \\
13.3 \pm 0.11\end{array}$} \\
\hline-4 & Treatment & & & & & \\
\hline & Control & $5.41 \pm 0.74$ & $3.73 \pm 0.37$ & $111.76 \pm 6.04$ & $17.18 \pm 1.16$ & $13.21 \pm 0.09$ \\
\hline \multirow[t]{2}{*}{-3} & Treatment & $4.74 \pm 2.72$ & $3.66 \pm 0.55$ & $107.52 \pm 4.33$ & $19.63 \pm 1.29$ & $12.04 \pm 0.18$ \\
\hline & Control & $5.04 \pm 1.97$ & $3.72 \pm 0.34$ & $103.02 \pm 5.52$ & $19.36 \pm 1.43$ & $12.12 \pm 0.19$ \\
\hline \multirow[t]{2}{*}{-2} & Treatment & $5.18 \pm 0.66$ & $3.50 \pm 0.45$ & $95.65 \pm 4.78$ & $18.96 \pm 1.51$ & $11.04 \pm 0.17$ \\
\hline & Control & $5.12 \pm 0.99$ & $3.75 \pm 0.46$ & $93.95 \pm 5.28$ & $18.02 \pm 1.54$ & $10.52 \pm 0.09$ \\
\hline \multirow[t]{2}{*}{-1} & Treatment & $4.79 \pm 0.70$ & $3.60 \pm 0.43$ & $78.44 \pm 7.43$ & $19.37 \pm 1.00$ & $8.96 \pm 0.15$ \\
\hline & Control & $4.50 \pm 0.58$ & $3.42 \pm 0.22$ & $77.42 \pm 11.51$ & $16.44 \pm 1.00$ & $9.16 \pm 0.13$ \\
\hline \multirow[t]{2}{*}{$\mathbf{0}$} & Treatment & $4.97 \pm 0.62$ & $3.31 \pm 0.49$ & $67.62 \pm 5.53$ & $18.51 \pm 1.63$ & $13.17 \pm 0.07$ \\
\hline & Control & $4.72 \pm 0.51$ & $3.12 \pm 0.49$ & $71.10 \pm 9.69$ & $18.30 \pm 1.35$ & $13.32 \pm 0.08$ \\
\hline \multirow[t]{2}{*}{1} & Treatment & $5.21 \pm 0.40$ & $3.42 \pm 0.57$ & $77.09 \pm 9.57 *$ & $20.77 \pm 1.51$ & $15.86 \pm 0.19$ \\
\hline & Control & $4.94 \pm 0.45$ & $3.39 \pm 0.48$ & $89.31 \pm 5.78$ & $18.65 \pm 1.89$ & $16.09 \pm 0.14$ \\
\hline \multirow[t]{2}{*}{2} & Treatment & $4.97 \pm 0.97$ & $3.78 \pm 0.35$ & $106.84 \pm 7.75$ & $18.10 \pm 1.66$ & $16.7 \pm 0.16$ \\
\hline & Control & $4.96 \pm 0.45$ & $3.54 \pm 0.34$ & $106.73 \pm 8.83$ & $20.21 \pm 1.74$ & $16.96 \pm 0.16$ \\
\hline \multirow[t]{2}{*}{3} & Treatment & $5.65 \pm 1.50$ & $3.75 \pm 0.40$ & $123.92 \pm 13.31$ & $20.27 \pm 1.62$ & $16.9 \pm 0.15^{*}$ \\
\hline & Control & $5.31 \pm 0.61$ & $3.70 \pm 0.36$ & $124.48 \pm 8.41$ & $19.69 \pm 1.42$ & $17.43 \pm 0.15$ \\
\hline \multirow[t]{2}{*}{4} & Treatment & $5.44 \pm 1.30$ & $3.86 \pm 0.36$ & $154.94 \pm 10.65^{*}$ & $21.13 \pm 1.64$ & $17.26 \pm 0.26^{*}$ \\
\hline & Control & $5.77 \pm 0.37$ & $3.92 \pm 0.42$ & $140.93 \pm 8.17$ & $18.67 \pm 1.52$ & $17.97 \pm 0.13$ \\
\hline \multirow[t]{2}{*}{5} & Treatment & $5.37 \pm 0.93$ & $3.87 \pm 0.32$ & $164.31 \pm 7.27 *$ & $19.90 \pm 1.57$ & $16.9 \pm 0.15^{*}$ \\
\hline & Control & $5.77 \pm 1.34$ & $4.02 \pm 0.43$ & $157.80 \pm 6.50$ & $19.58 \pm 1.67$ & $17.34 \pm 0.1$ \\
\hline \multirow[t]{2}{*}{6} & Treatment & $5.87 \pm 1.06$ & $3.86 \pm 0.36$ & $172.65 \pm 5.15^{*}$ & $19.64 \pm 0.91$ & $16.61 \pm 0.23$ \\
\hline & Control & $5.75 \pm 1.34$ & $3.69 \pm 0.44$ & $164.80 \pm 3.01$ & $16.88 \pm 0.81$ & $16.95 \pm 0.2$ \\
\hline \multirow[t]{2}{*}{7} & Treatment & $5.84 \pm 0.69$ & $3.93 \pm 0.38$ & $177.14 \pm 4.04 *$ & $18.55 \pm 1.47$ & $16.73 \pm 0.2$ \\
\hline & Control & $6.48 \pm 0.75$ & $3.67 \pm 0.61$ & $172.81 \pm 3.75$ & $21.53 \pm 1.56$ & $17.13 \pm 0.07$ \\
\hline \multirow[t]{2}{*}{8} & Treatment & $5.51 \pm 0.55$ & $3.83 \pm 0.23$ & $189.37 \pm 6.73 *$ & $17.86 \pm 1.54$ & $17.37 \pm 0.1$ \\
\hline & Control & $6.38 \pm 1.13$ & $4.17 \pm 0.63$ & $182.17 \pm 6.21$ & $15.75 \pm 1.62$ & $17.22 \pm 0.12$ \\
\hline
\end{tabular}

Columns having asterisk symbols differ significantly $(* \mathrm{P}<0.05)$ between groups at each sampling week 
In general, nutritional strategy to supplement antioxidants (Vitamin E, Selenium) and high energy diet reduces the concentration of urea, increases cholesterol level and have no effects on concentrations of ALT, total protein and albumin in the serum of periparturient cows.

\section{Acknowledgements}

We thank Director ICAR-IVRI for providing the necessary facilities for conducting this research work.

\section{References}

Allen MS, Bradford BJ, Harvatine KJ. 2005. The cow as a model to study food intake regulation. Annu Rev Nutr. 25: 523-47.

Bass, I.I. and Thompson, R., 1999. Effects of vitamin $\mathrm{E}$ supplementation in late gestation cattle and evaluation of vitamin E, cholesterol, and phospholipid relationships in bovine serum and serum lipoproteins (Doctoral dissertation, Virginia Tech).

Bell, AW, 1995. Regulation of organic nutrient metabolism during transition from late pregnancy to early lactation. Journal of animal science, 73(9), pp.2804-2819.

Bertoni, G. and Trevisi, E. 2008. Diet-health relationship in the transition period: consequences on energy balance and efficiency. In: Book of Abstracts 59th Annual Meeting of the Europian Association for Animal Production. Wageningen Academic Publishers. pp. 84.

Bhimte, A., Konyak, Y., Balamurugan, B., Singh, L.K., Sarkar, M., Singh, G. and Maurya, VP, 2018. Effect of Supplementation of Antioxidant (Vitamin E), Trace Minerals (Selenium, Copper, Zinc) and Increased Energy Allowance on (certain) Serum Metabolites and Competence of
Transition Crossbred Cows. Int. J. Curr. Microbiol. App. Sci, 7(7), pp. 439-447.

Bickerstaffe, R., Annison, E. F. and Linzell, J. L., 1974. The metabolism of glucose, acetate, lipids and amino acids in lactating dairy cows. J. Agric. Sci. 82:71-85.

Chandra, G., Aggarwal, A., Kumar, M. and Singh, A.K., 2018. Effect of zinc and vitamin E supplementation on hormones and blood biochemicals in peripartum Sahiwal cows. Journal of Trace Elements in Medicine and Biology, 50, pp.489-497.

Djoković, R., Kurćubić, V., Ilić, Z., Cincović, M., Petrović, M., Fratrić, N. and Jašović, B., 2013. Evaluation of metabolic status in Simmental dairy cows during late pregnancy and early lactation. Veterinarskiarhiv, 83(6), pp.593-602.

Drackley, J. K., 1999. Biology of dairy cows during the transition period: the final frontier? J. Dairy Sci. 82(11): 22592273.

Du, X., Chen, L., Huang, D., Peng, Z., Zhao, C., Zhang, Y., Zhu, Y., Wang, Z., Li, X. and Liu, G., 2017. Elevated apoptosis in the liver of dairy cows with ketosis. Cellular Physiology and Biochemistry, 43(2), pp. 568-578.

Duske, K., Hammon, H.M., Langhof, A.K., Bellmann, O., Losand, B., Nürnberg, K., Nürnberg, G., Sauerwein, H., Seyfert, H.M. and Metges, C.C., 2009. Metabolism and lactation performance in dairy cows fed a diet containing rumen-protected fat during the last twelve weeks of gestation. Journal of dairy science, 92(4), pp. 1670-1684.

Esposito, G., Irons, P.C., Webb, E.C. and Chapwanya, A., 2014. Interactions between negative energy balance, metabolic diseases, uterine health and immune response in transition dairy cows. Animal reproduction science, 
144(3-4), pp.60-71.

González, F.D., Muiño, R., Pereira, V., Campos, R. and Benedito, JL, 2011. Relationship among blood indicators of lipomobilization and hepatic function during early lactation in high-yielding dairy cows. Journal of veterinary science, 12(3), pp.251-255.

Guedon, L., Saumande, J., Dupron, F., Couquet, C. and Desbals, B., 1999. Serum cholesterol and triglycerides in postpartum beef cows and their relationship to the resumption of ovulation. Theriogenology, 51(7), pp.1405-1415.

Herdt, T. H., 2000. Ruminant adaptation to negative energy balance. Influences on the etiology of ketosis and fatty liver. Vet. Clin. North Am. Food Anim. Pract. 16(2): 215-230.

Pysera, B. and Opalka, A., 2000. The effect of gestation and lactation of dairy cows on lipid and lipoprotein patterns and composition in serum during winter and summer feeding. Journal of Animal and Feed Sciences, 9(3), pp.411-424.

Sordillo, L. M., 2005. Factors affecting mammary gland immunity and mastitis susceptibility. Livest. Prod. Sci. 98(12): 89-99.

Trevisi, ERMINIO, Amadori, M., Cogrossi, SIMONE, Razzuoli, E. and Bertoni, G., 2012. Metabolic stress and inflammatory response in high-yielding, periparturient dairy cows. Research in veterinary science, 93(2), pp.695-704.

Weiss, W. P. and Spears, J. W., 2006. Vitamin and trace mineral effects on immune function of ruminants. In:Sejrsen, K., Hvelplund, T. and Nielsen, M. O. eds. Ruminant Physiology: Digestion, Metabolism and Impact of Nutrition on gene expression, immunology \& stress. Wageningen Academic Publishers, Utrecht, The Netherlands. pp. 473-496.

\section{How to cite this article:}

Patel Pankaj, A., A. Khatti, A. Paul, D. Mahato, V. P. Maurya and Singh, G. 2020. Effect of Vitamin E and Selenium Supplementation on Serum Metabolites Concentration during PeriParturient Stress Period in Crossbred Cows. Int.J.Curr.Microbiol.App.Sci. 9(06): 3758-3763. doi: https://doi.org/10.20546/ijcmas.2020.906.444 